\title{
The Influence of Leadership Styles on Employee Mood and Job Performance: A Study of Hotels and Restaurants in Ho Chi Minh City, Vietnam
}

\author{
Mai Ngoc Khuong and Lu Kim Khanh
}

\begin{abstract}
This research mainly focused on studying the influence of different leadership styles on employee mood and job performance, targeting four-five star hotel and restaurant from middle-scale. Applying the quantitative method with 350 respondents, the study tested the effects of seven leadership styles including: task oriented leadership, relation oriented leadership, change oriented leadership, ethical leadership, charismatic leadership, participate leadership and autocratic leadership, on employee positive and negative mood and job performance. Through this research, it was confirmed that there is a relationship between leadership behavior and mood, between mood and job performance; and between leadership and job performance. Furthermore, it was also measured the indirect effect of Participate and Relation Oriented leadership style on job performance using mood as a mediators.
\end{abstract}

Index Terms-Leadership, hospitality, positive mood, negative mood, job performance.

\section{INTRODUCTION}

Hospitality and tourism, within service industry, is the world's largest and fastest growing industry, which consist of various fields such as travel and tourism, lodging, assembly and event management, restaurant and managed service and recreation. Four main characteristics of hospitality which are intangibility, inseparability, perishability and variability challenge the business owner on how to appeal and attract the customer. The competition to lead this industry is becoming fiercer when new players keep entering and stirring the market with new ideas and concepts. In 2014, according to Vietnam General Statistics Office [1], the total international arrivals coming to Vietnam reached 7,874,300, increase $4 \%$ comparing to 2013. However, the increasing rate of international tourists was lower than the rates of 2013 $(10,6 \%)$. The occupancy and room rate of four and five star hotels in HCMC decreased 6,7\% which affected the whole hotel business including others services, more or less. The pressure for luxury and upscale hotel and restaurant become heavier due to new competitors, high turnover rate and rare skillful workers.

With numerous similarly ideas and product, the only difference is the service level and service provider. Hospitality leader need to understand that in this service industry, rather than infrastructure and facilities, human

Manuscript received March 17, 2016; revised July 7, 2016.

The authors are with the School of Business, International University VNU-HCM, Vietnam (e-mail: mnkhuong@hcmiu.edu.vn, lkkhanh0608@gmail.com). resource or employee plays the main role in helping the organization achieve its goal. The service cannot be delivered or completed without the involvement of employee. Employee excellent performance will yield not only a good customer service but also higher achievement for the organization. Among the founded factors affecting job performance, previous researchers have discovered that one way to enhance the work outcome is related to employee's mood. However, there has been little research on linking between employee's mood and job performance especially in hospitality industry. Thus, this research aim to prove and measure the impact of different leadership style on employee mood and job performance, discuss the relationship between leader and employee in hospitality and recommend how to improve job performance through employee's mood and leadership behavior in hospitality industry in HCMC.

\section{LITERATURE REVIEW}

\section{A. Task Oriented Leadership}

Task oriented leadership is defined as leaders who put their focus on how to completing a task perfectly. This involves behaviors including assigning task, setting rules, establishing communication method, controlling performance and giving feedback to followers. In general, task oriented leaders tend to explain clearly how a function need to be accomplished and have top-down communication structure which means employees are forced to follow leader's instruction [2]. They provide employees working structure and motivate them to complete the task using that structure [3]-[5]. [6] stated that task oriented leader had the ability to focus on problems, positively adapt to difficult situations by their directing and reduce the stress amount. Furthermore, task oriented strategies have a better adjustments, yield higher productivity and cause less depression [7], [8].

\section{B. Relation Oriented Leadership}

Relation oriented leadership is defined as the degree to which leaders care for their follower's benefit and welfare, focus on the relationship with employees, show them respects, appreciation and support [9], [10]. With relation oriented leader, subordinates are allowed to raise their voice, share their idea or opinion and leaders take those into consideration before making decision. Opposite with task oriented leadership, in relation oriented leadership, the communication between leaders and followers is informal [11] which can help avoiding misunderstanding and fast recognizing mistake to fix it [12]. Furthermore, employee whose leader is relation 
oriented can do their task freely without the leader's interfere and control which means they can develop their creativity, seek ways to learn and gain skill and knowledge [13], [5]. It is also proved that relation oriented leadership can reduce employee turnover [14] and help reaching a higher level of employee motivation [15].

\section{Change Oriented Leadership}

Change oriented leadership is who has the aptitude to adapt to changes and easily get familiar with it. Change oriented leader tend to have a persuasive method to communicate with people about changes. It is also proved that change oriented leadership positively affect employee motivation, organizational commitment and evaluation of leader's competence [16]. Change oriented leaders mostly concern with how to adapt to new environment, how to improve strategic decisions and increase the innovation, how to be creativity and keep on seeking ways to change for a better performance [17]. In addition, change oriented leaders have the ability to measure the influence of environment change to come up with an innovative ways such as strategies, product or service to deal with those changes. It requires skill to combine, integrate and make variation between environment change and individual colors [18], [19].

\section{Participative Leadership}

The concept of participative leadership is understood as leaders who encourage and motivate their followers to take part in the discussion to make a joint influence on the decision making process, based on everybody's opinion, not just the leader's solely [20]. The purpose of this type of leadership is let employee to be self-directed, self-motivated, be independent and develop their spontaneous effort. It is proved that this may yield higher job satisfaction of employee [21]. Participative leadership is also described as the ability to manage the group discussion, solving conflict and communication issues, make people feel comfortable to raise their voice [17]. [22] stated that democratic decision-making can prevent employee's negative issue at workplace such as low self-esteem, isolation, low motivation and productivity.

\section{E. Charismatic Leadership}

Charismatic leadership refers to the ability to stand out among the crowd and make followers believe that their leaders have special characteristic that call for attraction. [23] mentioned that charismatic leaders tend to be extremely expressive with extraordinary aptitude in persuading, affecting and motivating people. In an organization, it is found that charismatic leadership has a significant influence on employee's self-value perception, attitude and behavior. For instance, charismatic leader can affect self-expression, self-consistency, self-esteem and trust of employees [24]. In addition, it is proposed that charismatic positively influence organization's performance and financial health by motivating employees to work beyond expectation [23], [25], [26].

\section{F. Autocratic Leadership}

Ref. [27] described autocratic leader as someone "power-oriented, arbitrary, closed-minded, coercive and punitive". Similarly, autocratic leadership is used to talk about someone who refers using power to take dominance and authoritarian, whose main interest are themselves, tend to self-exalt and take advantage of others [28]. This type of leadership favors dominating, controlling, holding grudge and revenging [29]-[31]. However, in a modern workplace where the environment becomes tougher and fiercer, autocratic leadership is believed as not an ideal leadership style that can fight against the leadership challenges. Globalization and economy knowledge allow followers increase their capability, become independent and be knowledgeable, enough to not accept being controlled and under autocratic leadership [32]. However, it is also believed that this type of leadership can be useful only in an emergency case that requires completing task urgently [33].

\section{G. Ethical Leadership}

Ethical leadership is defined as "the demonstration of normatively appropriate conduct through personal action and interpersonal relationships and the promotion of such conduct to followers through two ways communication, reinforcement and decision making"[34]. There are several outstanding traits of ethical leadership such as strong belief in justice, caring, transparent, trustworthy, refer open communication and focus on creating and shaping ethical culture and behavior among followers [34]. Ethical leaders tend to set a moral standard, spend their effort on inspiring people follow the rule and keeping the justice at workplace. The influence of ethical leadership on employee's job performance was proved as positive. For instance, it is founded that skillful ethical leadership can enhance work outcome, job involvement and affective commitment of managers in Indian private and public sector [35]. It support the result of [36], proved that ethical leadership has a directly positive affect to group-level organizational citizenship behavior and negative affect with group-level deviance. Furthermore, ethical leadership also causes impact on the turnover rate of an organization. It related to the follower's job dedication, honesty and consideration for unethical issue that happened [34].

\section{H. Positive Mood}

Moods are described as permeating and broad affective states which have wide-ranging effects on behavior and cognitive processes [37]-[39]. In mood-as-information theory, [39] stated that mood help people receive information about the situation and make adaption to different environment through thought processes and behavior [38]. Mood can be divided into positive and negative [40]. Positive mood helps perceiving the unproblematic environment, hence, people become more relax, think more divergently, solve problem more heuristically [41]-[45], whereas negative moods alert people about the problems, make them focus on figuring out the error and fixing it, devote more effort on improving the matter [39], [44], [46], [47].

In the past years, there have been researches on mood at work place, its source and effect. It is found that leaders and employees interaction get affected by each other's moods and this will influence employee organizational behaviors [48]. [49] stated that transformational leadership could raise employee emotion that motivates them to achieve organizational vision. In the research of [50], the result 
proved that transformational leadership can enhance employee task performance through employee positive mood. This shows the same result with [51] that leaders who provide employees training, knowledge and chance to challenge themselves, show confidence in the employee's ability and make employees feel their importance in the organization will help employee experience more positive mood. [52] stated that transformational leadership has strong connection with employee's positive emotion while transactional leadership is connected with negative emotion.

It is noted that employee with positive moods are more creative, more helpful and more patient in performing task than those with lower positive moods [53], [54]. This is consistent with the research's result of [55] in which positive employee offers helping behavior toward customers and coworkers more. Similarly, the result of study on salespeople of large retail store by [56] showed that employees with positive mood are more likely to assist customers and coworker, as consequences, increase the store's sale. On the contrary, negative emotion may decrease working motivation and high-level performance [57]. In [52], it was founded that negative emotion had a significant impact on performance. [46] reported that positive mood led to better creative outcome but it also make employee over-self-satisfaction that lead to reducing creativity. Similarly, negative mood have two opposite impacts on creativity. Despite it is believed to have negative relationship with creativity, negative mood, if being considered thoroughly, it has positive impact on creativity. Moreover, it was studied that individuals who are in negative mood tend to have difficulty in trusting others and deny the co-operation [58]. It is also proved that negative mood influence team performance negatively.

\section{Job Performance}

Performance refers to multi-dimensions construct described employee behaviors and activities in fulfilling goals of an organization [59]. Not every behavior at work place is considered as performance but only those with the aims to reach the organizational goal [60]. Employee performance is job-related activities and how well the employees execute these activities. Therefore, performance comprises actions carried by employee after a standard period and those actions must go through judgmental and evaluative processes [61], [62]. Moreover, only actions than can be measured and rated are seen as performance [60].

\section{Methodology}

\section{A. Questionnaire Design and Data Collection}

In this study, researcher applied quantitative method to collect the data serving for statistics analysis.

The research used primary data achieved from the survey which will be conducted offline only. Questionnaires are sent to front-line employees of four and five star hotel and middle scale up up-scale restaurants in Ho Chi Minh City with clear guidance for them to answer correctly. The list of four and five stars hotel will be based on the approval of Vietnam Tourism Ministry. Respondent are asked to give their opinion about their leader's leadership style and how it affect their daily mood and job performance by following the 5-point Likert Scale from 1- Strongly Disagree to 5-Strongly Agree.

After one month of conducting the survey, there were total 352 qualified cases for data analysis.

\section{B. Data Analysis}

To analyze the data, this study applied SPSS (Statistical Package for the Social Sciences) statistical software version 20.0. First, Exploratory Factor Analysis (EFA) and Reliability Test were conducted to extract the interrelationships among variables and to check the reliability and validity of them. Next, Multiple Regression and Path Analysis were employed to identify the relationships between dependent and independent variables. Lastly, based on the data analysis result, research hypotheses conclusion was made.

\section{Factor Analysis and Reliability}

For this study, there are two separated Exploratory Factor Analyses (EFA) for dependent variables and independent variable were conducted with Kaiser-Meyer-Olkin and Barltlett's test of sphericity and Varimax Rotation.

TABLE I: SUMMARY OF INDEPENDENT VARIABLES

\begin{tabular}{|l|c|c|}
\hline \multicolumn{1}{|c|}{ Variable } & $\begin{array}{c}\text { Number of } \\
\text { item }\end{array}$ & $\begin{array}{c}\text { Cronbach's } \\
\text { Alpha }\end{array}$ \\
\hline Positive mood & $6^{*}$ & .884 \\
\hline Negative mood & $6^{*}$ & .888 \\
\hline Job performance & $5^{*}$ & .682 \\
\hline
\end{tabular}

* All items have factor loadings $\geq 0.5$

KMO index $=.930$

Sig. of Bartlett's test $=.000$

Total variance explained $=67.880 \%$

According to Table I, KMO index is .930 which is marvelous and Bartlett's Test of Sphericity sig. value is .000. Therefore, this data is considered appropriate for factor analysis. The table also indicated 7 components which were rated appropriate for retaining and explained 67.880 percent of the total variance. The result also showed that after the Varimax rotation, all items of 7 leadership styles have factor loading greater than .5. Furthermore, for the validation and internal consistency test, all the Cronbach's alphas are greater than .7 which is acceptable.

TABLE II: SUMMARY OF DEPENDENT VARIABLES

\begin{tabular}{|l|c|c|}
\hline \multicolumn{1}{|c|}{ Variable } & $\begin{array}{c}\text { Number of } \\
\text { item }\end{array}$ & $\begin{array}{c}\text { Cronbach's } \\
\text { Alpha }\end{array}$ \\
\hline Task oriented leadership & $5^{*}$ & .928 \\
\hline Relation oriented leadership & $5^{*}$ & .837 \\
\hline Change oriented leadership & $4^{*}$ & .861 \\
\hline Participative leadership & $5^{*}$ & .893 \\
\hline Charismatic leadership & $4^{*}$ & .819 \\
\hline Autocratic leadership & $7^{*}$ & .806 \\
\hline Ethical leadership & $5^{*}$ & .704 \\
\hline
\end{tabular}

* All items have factor loadings $\geq 0.5$

KMO index $=.860$

Sig. of Bartlett's test $=.000$

Total variance explained $=59.399 \%$

Similarly, the Table II shows that the KMO index is .860 and the significance of Bartlett' test is .000 which is appropriate to conduct the factor analysis. Moreover, the 3 dependent variables explain 59.399 percent of the total variance with all factors loading greater than .5 and 
Cronbach's Alpha ranged from .682 to .888 which is acceptable.

\section{RESEARCH FINDINGS}

\section{A. Profile of the Sample}

Table III described the characteristics of the respondents participating in the survey. As can be seen from the table, the number of male and female respondents had an average gap, $46.9 \%$ and $53.1 \%$ respectively and the majority of the respondents was employee $(74.1 \%)$ and followed by junior manager $(21.9 \%)$ and middle manager (4\%). Moreover, most of the employees participating in answering the questionnaire have from less than 1 year to 4 year experience (account for $90.1 \%$ in total) most of them has at least graduated from high school. Besides, there were 291 respondents were single and the age from 18-35 took the largest quantity in 352 respondents.

\section{B. Factors Affecting Employee Mood and Job Performance}

Table IV illustrates the correlation between dependent and independent variables.

Regarding positive mood, the table revealed that except for autocratic leadership ( $r=-.109)$, all the other styles of leadership have positive correlation with employee positive mood. The table also showed the correlation between autocratic leadership ( $r=.649)$; task oriented leadership $(r=-.319)$ and employee negative mood.

TABLE III: PERSONAL INFORMATION $(N=426)$

\begin{tabular}{|c|c|c|c|}
\hline Measure & Items & Frequency & Percentage \\
\hline Position & $\begin{array}{l}\text { Employee } \\
\text { Junior manager } \\
\text { Middle manager }\end{array}$ & $\begin{array}{c}261 \\
77 \\
14 \\
\end{array}$ & $\begin{array}{c}74.1 \\
21.9 \\
4.0 \\
\end{array}$ \\
\hline Gender & $\begin{array}{l}\text { Male } \\
\text { Female }\end{array}$ & $\begin{array}{l}165 \\
187\end{array}$ & $\begin{array}{l}46.9 \\
53.1\end{array}$ \\
\hline Marital Status & $\begin{array}{l}\text { Single } \\
\text { Married }\end{array}$ & $\begin{array}{c}291 \\
61\end{array}$ & $\begin{array}{l}82.7 \\
17.3\end{array}$ \\
\hline Age & $\begin{array}{l}18-25 \\
25-35 \\
35-45 \\
45-55 \\
>55\end{array}$ & $\begin{array}{c}225 \\
109 \\
15 \\
2 \\
1 \\
\end{array}$ & $\begin{array}{c}63.9 \\
31.0 \\
4.3 \\
.6 \\
.3\end{array}$ \\
\hline Experience & $\begin{array}{l}<1 \text { year } \\
1-4 \text { years } \\
4-7 \text { years } \\
7-10 \text { years } \\
\text { Over } 10 \text { years }\end{array}$ & $\begin{array}{c}147 \\
170 \\
29 \\
4 \\
2 \\
\end{array}$ & $\begin{array}{c}41.8 \\
48.3 \\
8.2 \\
1.1 \\
.6\end{array}$ \\
\hline $\begin{array}{l}\text { Educational } \\
\text { Level }\end{array}$ & $\begin{array}{l}\text { High School } \\
\text { Vocational School } \\
\text { College } \\
\text { University } \\
\text { Post University }\end{array}$ & $\begin{array}{c}68 \\
82 \\
101 \\
100 \\
1\end{array}$ & $\begin{array}{c}19.3 \\
23.3 \\
28.7 \\
28.4 \\
.3 \\
\end{array}$ \\
\hline
\end{tabular}

TABLE IV: CORRELATIONS BETWEEN VARIABLES

\begin{tabular}{|l|c|c|c|c|c|c|c|c|c|c|}
\hline & JOB & 1 & 2 & 3 & 4 & 5 & 6 & 7 & 8 & 9 \\
& PER & & & & & & & & & \\
\hline 1.POSI & .104 & & & & & & & & & \\
2.NEGA & -.117 & -.199 & & & & & & & & \\
3.AUTO & -.069 & -.109 & .649 & & & & & & & \\
4.TASK & .353 & .416 & -.319 & -.335 & & & & & & \\
5.ETHI & .353 & .505 & -.225 & -.188 & .581 & & & & & \\
6.PART & .228 & .566 & -.254 & -.299 & .588 & .671 & & & & \\
7.RELA & .290 & .576 & -.283 & -.234 & .547 & .655 & .641 & & & \\
8.CHAR & .258 & .512 & -.264 & -.206 & .584 & .648 & .705 & .580 & & \\
9.CHAN & .352 & .418 & -.216 & -.221 & .555 & .564 & .563 & .473 & .542 & \\
\hline Mean & 3.73 & 3.24 & 2.51 & 2.35 & 3.69 & 3.68 & 3.58 & 3.49 & 3.55 & 3.80 \\
\hline S.D & .50 & .66 & .81 & .88 & .60 & .69 & .72 & .74 & .66 & .59 \\
\hline
\end{tabular}

In the case of job performance, task oriented leadership $(r=.353)$, ethical leadership $(r=.353)$ and change oriented leadership $(r=.352)$ were proved to have correlation with employee job performance.

TABLE V: COEFFICIENTS BETWEEN LEADERSHIP AND POSITIVE MOOD

\begin{tabular}{|l|c|c|}
\hline \multicolumn{1}{|c|}{ Model } & $\begin{array}{c}\text { Standardized } \\
\text { Coefficients } \\
\text { (Beta) }\end{array}$ & Sig. \\
\hline Constant) & & .052 \\
\hline Autocratic Leadership & .085 & .055 \\
\hline Task Oriented Leadership & .005 & .926 \\
\hline Ethical Leadership & .036 & .576 \\
\hline Participative Leadership & .248 & .000 \\
\hline Relation Oriented Leadership & .317 & .000 \\
\hline Charismatic Leadership & .109 & .089 \\
\hline Change Oriented Leadership & .065 & .238 \\
\hline
\end{tabular}

*Coefficient is significant at the .05

ANOVA: $\mathrm{F}=35.167$, Sig. $=.000$

Model summary: R Square $=.417$

The Table V shows that only participate leadership and relation oriented leadership significantly affect employee positive mood with sig. $=.000$. The others dimension do not meet the requirement $(p>.05)$. Relation oriented leadership has the highest beta value (.317), following by participate leadership (.248). This indicates that relation oriented leadership makes the strongest contribution to employee positive mood whereas participate leadership takes the second position.

$H_{1}$ : Relation oriented leadership and participative leadership significantly affect employee positive mood (Accepted)

TABLE VI: COEFFICIENTS BETWEEN LEADERSHIP AND NEGATIVE MOOD
\begin{tabular}{|l|c|c|}
\hline \multicolumn{1}{|c|}{ Model } & $\begin{array}{c}\text { Standardized } \\
\text { Coefficients } \\
\text { (Beta) }\end{array}$ & Sig. \\
\hline (Constant) & .617 & .000 \\
\hline Autocratic Leadership & -.045 & .000 \\
\hline Task Oriented Leadership & -.011 & .828 \\
\hline Ethical Leadership & .127 & .056 \\
\hline Participative Leadership & -.115 & .047 \\
\hline Relation Oriented Leadership & -.129 & .038 \\
\hline Charismatic Leadership & .005 & .920 \\
\hline Change Oriented Leadership & & \\
\hline
\end{tabular}

*Coefficient is significant at the .05

ANOVA: $F=40.360$, Sig. $=.000$

Model summary: R Square $=.451$ 
The Table VI displays autocratic leadership, charismatic leadership and relation oriented leadership significantly affect employee negative mood with sig. $=.000$. Autocratic leadership has the highest contribution to the dependent variable (.617), following by charismatic leadership (-.129) and relation oriented leadership (-.115).

$\mathrm{H}_{2:}$ Autocratic leadership, Charismatic leadership and Relation oriented leadership significantly affect employee negative mood (Accepted)

TABLE VII: COEFFICIENTS BETWEEN LEADERSHIP, EMPLOYEE MOOD AND

\begin{tabular}{|l|c|c|}
\hline \multicolumn{1}{|c|}{ Model } & $\begin{array}{c}\text { Stan PERFORMANCE } \\
\text { Coefficients } \\
\text { (Beta) }\end{array}$ & Sig. \\
\hline Constant) & & .000 \\
\hline Autocratic Leadership & .093 & .159 \\
\hline Task Oriented Leadership & .204 & .003 \\
\hline Ethical Leadership & .206 & .007 \\
\hline Participative Leadership & -.108 & .185 \\
\hline Relation Oriented Leadership & .131 & .071 \\
\hline Charismatic Leadership & -.009 & .900 \\
\hline Change Oriented Leadership & .212 & .001 \\
\hline Employee Positive Mood & -.183 & .004 \\
\hline Employee Negative Mood & -.049 & .448 \\
\hline
\end{tabular}

*Coefficient is significant at the .05

ANOVA: $\mathrm{F}=10.129$, Sig. $=.000$

Model summary: $\mathrm{R}$ Square $=.210$

The Table VII displays that 4 variables including task oriented leadership, ethical leadership, change oriented leadership and employee positive mood significantly affect employee job performance with sig. $=.000$. The others variable have the sig. value greater than .05 hence, it is concluded that they do not have significant effect to job performance. Change oriented leadership makes the strongest contribution (.212) to employee job performance, then continue with ethical leadership (.206) whereas task oriented leadership is in third place (.204) and employee positive mood take the last (-.183).

$H_{3}$ : Task oriented leadership, ethical leadership, change oriented leadership and employee positive mood significantly affect job performance (Accepted)

\section{Indirect Effect and Causal Effect of Job Performance}

The indirect effect of an independent variable on the dependent variable through the mediate one is formed by the total product of the effect of that independent variable on the mediate variable and the effect of the mediate variable on the dependent variable [63].

As mentioned, relation oriented and participative leadership directly and positively affected employee positive $\operatorname{mood}\left(\mathrm{H}_{1}\right)$. Then employee positive mood directly caused an effect on job performance $\left(\mathrm{H}_{3}\right)$. Consequently, relation oriented leadership and participative leadership created indirect effects on Return intention, mediated by employee positive mood. The Table VIII below summarizes the direct and indirect effect of leadership styles and employee mood on job performance.

The total effect of these factors on Job performance was .908 , in which direct effects accounted for more than $88 \%$ while indirect effects made up nearly $12 \%$.
TABLE VIII: DIRECT, INDIRECT AND TOTAL CAUSAL EFFECTS

\begin{tabular}{|c|c|c|c|}
\hline \multirow[t]{2}{*}{ Variables } & \multicolumn{3}{|c|}{ Causal Effects } \\
\hline & Direct & $\begin{array}{c}\text { Indire } \\
\text { ct }\end{array}$ & Total \\
\hline Positive mood & -.183 & ---- & -.183 \\
\hline Negative mood & ---- & ---- & ---- \\
\hline Autocratic leadership & ---- & ---- & ---- \\
\hline Task oriented leadership & .204 & ---- & .204 \\
\hline Ethical leadership & .206 & ---- & .206 \\
\hline Participative leadership & ---- & -.045 & -.045 \\
\hline Relation oriented leadership & ---- & -.058 & -.058 \\
\hline Charismatic leadership & ---- & ---- & ---- \\
\hline Change oriented leadership & .212 & ---- & .212 \\
\hline TOTAL & .805 & .103 & .908 \\
\hline
\end{tabular}

$H_{4}$ : The effect of Participative leadership and Relation oriented leadership on employee job performance is mediated by employee positive mood (Accepted)

\section{Path Diagram}

Fig. 1 used path diagram to represent structural model of relationship between leadership styles, employee mood and job performance using the final direct and indirect coefficients calculated above. Noted that all coefficients in the model were significant at the .05 level.

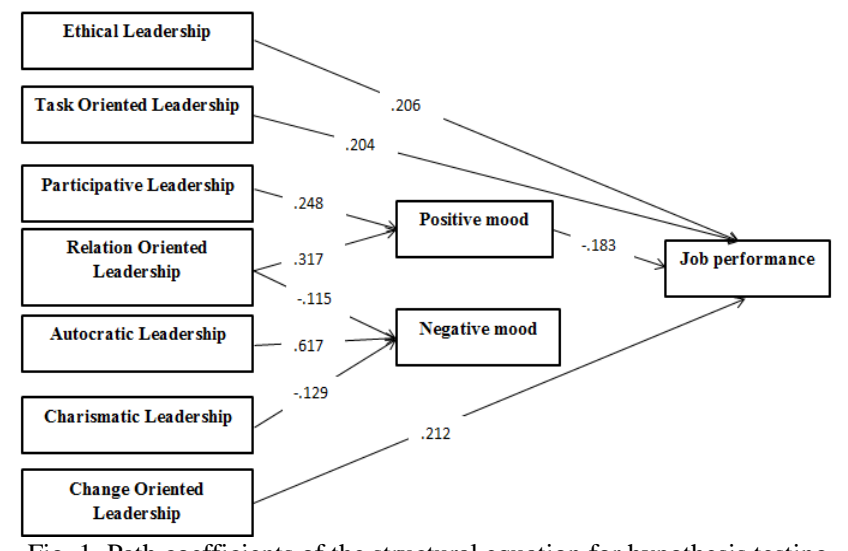

Fig. 1. Path coefficients of the structural equation for hypothesis testing.

\section{DISCUSSIONS AND RECOMMENDATIONS}

\section{A. Discussions}

As the result above, there are several worthy points that need to be noted down.

First of all, participative leadership and relation oriented leadership have a positive impact on employee mood and indirect impact on employee job performance. Participative leaders allow employees to take part in the organizational decision-making whereas relation oriented leadership described the closed relationship between leaders and followers and how leaders make followers feel being appreciated for their contribution to the company. Both types share common characteristics such as empowerment, great motivation skill, listening to employee's opinion and more. It is proved that leaders who express their belief in employee's ability and let them understand that they play a significant position in the organization will lead to employee's positive 
mood [51]. Moreover, participative and relation oriented leadership share the same traits as transformational leadership's intellectual stimulation and individualized consideration which was proved to have a positive effect on employee mood [50].

One of the common problems that happen between junior/middle manager and employees is that the managers often jump on conclusion and barely listen to employee's explanation. For instance, managers take sides of the ill manner guest and blame the employee without hearing the story. Most of employees will feel embarrassed when get scolded in front of the guest, hence, it will be better if the managers talk it out in a private place. Most of the time, front-line employees such as servers are the one who directly interact with the guest; therefore, they understand the demand and situation better than the managers do. When problem happens, they will absolutely feel more positive if the leaders trust them, listen to them, give advice and let them handle it with a careful and comfortable monitor rather than jump on conclusion and pressure them. In a harsh environment like hospitality industry where the salary is low, long working hours, heavy manual task, terrible pressure from the customer and if the leaders join in this force, employee will feel downhearted because their effort is not being recognized, feel tired of fighting with both sides and having to satisfy both. If leaders can show some sympathy over employee's situation, listen to their story, point out good and bad things in a suitable manner, then at least they can lift a piece of heaviness from their shoulder.

The second problem is that employees tend to feel a huge gap between managers and themselves, therefore, when they are in difficulty, it is hard for them to reach the help of managers. Managers should break this wall by showing the willingness to help. For instance, in a restaurant, simple actions such as clearing a table, taking order, serving food when the restaurant is crowded instead of rushing the waiter; will be appreciated. Moreover, in daily operation activities, employee has a huge involvement; therefore, any change that related to employee should be discussed before making decision. This decrease the dissatisfaction, increase chance for leader-employee interaction and open to more opinions which make employee feel being respected, appreciated and interestingly, get employee used to the leader's working style and both sides can explore each other's personality more. Small gesture such as asking "do you have any opinion?" or "do you need any help?" will lead to a huge change in the relationship between manager and employee. This helps employee's working day is just not only for working but also meeting friend and spending time with their favorite people who have the same career path and understand them.

Interestingly, people believe that good mood will lead to higher job performance. Previous researches also supported this idea. For example, employees with positive mood are more creative, more helpful and more patient in performing task [53]-[55] also stated that positive employee tend to offer more helping behaviors toward customers and colleague. [64] said that positive mood help employee become more constructive, more cooperate and have more integrative solution. In this research, even though it showed a low correlation, the result stated that positive mood has a negative relationship with job performance. This unexpected result was not supported by previous studies. However, [45] explored that even though positive mood can yield various ideas but the idea's quality is not at highest. Furthermore, [46] also explained that positive mood employees tend to be over-confident at the current situation and perform a lower level of creativity. Similarly, [65] suggested that people in positive mood spend less effort on performing syllogism task which might lead to a poor result. Therefore, by the result of this research, it is proved that positive mood does not always bring a better performance. This can be explained by the over-confidence, over-comfortableness and over self-satisfaction which make employees lack of striving effort. Hence, for participative and relation oriented leadership, despite it is good for the manager to get closed to employee, there still need a limitation. Manager need to know when to take serious and strong actions toward employee's mistake. Fairly treatment and feedback for both good and bad performance can make employee better-behaved. Employee should always be in caution that the close relationship with manager does not mean they can avoid the punishment for doing wrong.

Regarding negative mood, through this study, it is proved that autocratic leadership highly affect employee negative mood. Autocratic leaders are described as someone who over use their power to force employee to work according to their will. They do not allow any objection from others, refer using power to control everything and seek revenge for anyone against them. This type of leadership makes employees feel low self-esteem for not being recognized and respected. Moreover, by being forced to work against their will without being listened to make employee feel demotivated and stressful. While negative emotion is proved to have negative effect on job performance, in this research, it is not supported.

Last but not least, Change oriented leadership; Ethical leadership and Task oriented leadership are proved to have impact on job performance. The difference between the orders of effect is not high. Three of those types were also proved to have positive influence on job performance in many previous studies [7], [8], [23]-[26], [35].

In Vietnam hospitality industry, four-five star hotels and middle scale restaurants have low educational workforce. Most of the employees graduated from high school and vocational school. They refer manual working rather than intellectual working and it is easier for them to learn by doing rather than learn by reading. Therefore, one way for middle/junior managers to boost their skill and knowledge is giving them different tasks to work on. Keeping on practicing will make them used to the task and hence, their skill and knowledge will be improved. In employee's perspective, working with change oriented leadership give opportunities to share their idea and get motivated to take risk and challenge to improve themselves. In combination with task oriented leadership style where employee are instructed and monitored how to work, it helps saving more time, have more productivity and avoid making undesired mistake. Small changes such as task rotation among the employees can help creating chance for everyone to develop their skill and help managers avoiding bias thinking among the team.

One of the most considered issues in hospitality industry is 
food hygiene which relates to the customer well-being and business ethics issue. When the food hygiene issue becomes more serious, customers are willing to spend more money for a better service, to ensure the quality and hygiene. Small problem such as dirty cutleries and equipment can damage the reputation of a brand, not even mention bigger issue such as spoiled and poisonous food. The leader's role is to make sure the outer and inner quality of everything served for the guest must be perfect. Furthermore, customers really appreciated if their allergy can be taken note. Intentionally or not, serving food that cause customer's allergy is considered unethical. Therefore, leaders should pay attention to ethics issue, be a role model for their employee and have serious training session for this.

\section{B. Limitation}

The first limitation of the research happens with the sample size of 352 front-line employees of hotels and restaurant in HCMC. This number does not represent all hospitality employees; therefore, the result may not reflect all the opinion of employees in different area.

The second limitation is these seven types of leadership do not represent all the types of leadership that may influence employee mood and job performance. Therefore, a larger scale of research consist all of the leadership style should be conducted to come up with more suitable framework. Furthermore, moderating variable such as gender, age, educational level, experience and marital status should be further analyzed for its effect on perceiving mood and job performance.

\section{REFERENCES}

[1] International visitors to Viet Nam in December and 12 months of 2014 Vietnam General Statistics Office.

[2] R. M. Stogdill, "Leadership, membership and organization," Journal of Psychological Bulletin, vol. 47, pp. 1-14, 1950.

[3] R. J. House, "Path-goal theory of Leadership: Lessons, legacy and a reformulated theory," Journal of The Leadership Quarterly, vol. 7, pp. 323-352, 1996

[4] P. Hersey and K. Blanchard, "Life-cycle theory of Leadership," Journal of Training and Development, vol. 23, pp. 26-34, 1969.

[5] S. Kerr and M. Jermier, "Substitutes for Leadership - Their meaning and measurement," Journal of Organizational Behavior and Human Performance, vol. 22, pp. 375-403, 1978.

[6] J. E. Higgins and N. S. Endler, "Coping, life stress and psychological and somatic distress," European Journal of Personality, vol. 9, no. 4, pp. 253-270, 1995.

[7] D. L. Causey and E. F. Dubow, "Negotiating the transition to junior high school: The contributions of coping strategies and perceptions of the school environment," Prevention in Human Services, vol. 10, 1993.

[8] B. E. Compas, V. L. Malcarne, and K. M. Fondacaro, "Coping with stressful events in older children and young adolescents," Journal of Consulting and Clinical Psychology, vol. 56, no. 3, p. 405, 1988.

[9] B. M. Bass, Bass \& Stogdill's Handbook of Leadership, 3rd ed. New York: The Free Press, 1990a.

[10] B. M. Bass, "From transactional to transformational Leadership: Learning to share the vision," Journal of Organizational Dynamics, vol. 18, no. 3, pp. 19-31, 1990 b.

[11] G. Yukl, "Managerial leadership: A review of theory and research," Journal of Management, vol. 15, no. 2, pp. 251-289, 1989.

[12] B. Shamir, "Social distance and charisma: Theoretical notes and an exploratory study," Journal of Leadership Quarterly, vol. 6, pp. 19-47, 1995.

[13] C. L. Graeff, "The situational Leadership theory: A critical review," Academy of Management Review, vol. 8, pp. 285-291, 1983.
[14] E. Fleishman and E. Harris, "Patterns of Leadership behavior related to employee grievances and turnover," Personnel Psychology, vol. 15, pp. 43-56, 1962.

[15] J. Butler, S. Cantrell, and R. Flick, "Transformation leadership behaviors, upward trust and motivation in self-managed work teams," Journal of Organization Development, vol. 17, no. 1, pp. 13-25, 1999.

[16] A. Skogstad and S. Einarsen, "The importance of a Change-centred Leadership style in four organizational cultures," Scandinavian Journal of Management, vol. 15, pp. 289-306, 1999.

[17] G. Yukl, Leadership in Organizations, Prentice-Hall Inc., $5^{\text {th }}$ edition 2002.

[18] G. Yukl, Leadership in Organizations, Englewood Cliffs, NJ: Prentice hall, $7^{\text {th }}$ edition, 2010.

[19] J. P. J. de Jong and D. N Den Hartog, "Leadership and employees' innovative behavior," European Journal of Innovation Management, vol. 10, pp. 41-64, 2007.

[20] P. L. Koopman and A. F. M. Wierdsma, "Participative management," Handbook of Work and Organizational Psychology, vol. 3, pp. 297-324, 1998.

[21] S. Kim, "Participative management and job satisfaction: Lessons for management leadership," Public Administration Review, vol. 62, no. 2, pp. 231-241, 2002.

[22] S. J. Gibbs, Tribes Sausalito, CA: Center source system, p. 45, 1995.

[23] B. M. Bass, "Leadership: Good, better, best," Journal of Organizational Dynamics, vol. 13, no. 3, pp. 26-40, 1985.

[24] B. Shamir, R. J. House, and M. B. Arthur, "The motivational aspects of Charismatic Leadership: A self-concept theory," Journal of Organizational Science, vol. 4, pp. 1-17, 1993.

[25] J. M. Burns, Leadership, Harper \& Row, New York, 1978.

[26] R. J. House, "A 1976 theory of Charismatic Leadership," iLeadership: The Cutting Edge, Carbondale, IL: Southern Illinois University Press, pp. 189-207, 1977.

[27] B. M. Bass and R. Bass, "The bass handbook of leadership: Theory, research and managerial applications," Simon and Schuster, 2008.

[28] E. Aronson, "Integrating leadership styles and ethical perspectives," Canadian Journal of Administrative Sciences, vol. 18, no. 4, p. 244, 2001.

[29] B. M. Bass, Bass and Stogdill's Handbook of Leadership: Theory, Research and Managerial Applications, New York: Free Press, 1990.

[30] J. M. Howell and B. J. Avolio, "The ethics of charismatic leadership: Submission or liberation," Journal of Academy of Management Executive, vol. 6, pp. 43-54, 1992.

[31] D. C. McClelland, Power: The Inner Experience, New York: Irvington, 1975.

[32] C. M. Macneil, "Line managers: Facilitators of knowledge sharing in teams," Journal of Employee Relations, vol. 25, no. 3, pp. 294-307, 2003.

[33] B. Delia, S. Novi, and S. Serbia, "Leadership Styles and creativity," Journal of Applied Knowledge Management, vol. 1, pp. 64-75, 2013.

[34] M. E. Brown, L. K. Trevino, and D. A. Harrison, "Ethical Leadership: A social learning perspective for construct development and testing," Management International Review, vol. 34, no. 3, pp. 235-254, 2005.

[35] R. Khuntia and D. Suar, "A scale to assess Ethical Leadership of Indian private and public sector managers," Journal of Business Ethics, vol. 49, pp. 13-26, 2004

[36] D. M. Mayer, M. Kuenzi, R. Greenbaum, M. Bardes, and R. Salvador, "How low does ethical leadership flow? Test of a trickle-down model," Journal of Organizational Behavior and Human Decision Processes, vol. 11, no. 2, pp. 92-99, 2009.

[37] J. P. Forgas and P. T. Vargas, "The effects of mood on social judgments and reasoning," Handbook of Emotions, 2nd ed., New York: Guilford, pp. $350-367,2000$.

[38] N. Schwarz, "Emotion, cognition and decision making," Cognition and Emotion, vol. 14, pp. 433-440, 2000.

[39] N. Schwarz and Clore, "Mood as information," Psychological Inquiry, vol. 14, pp. 296-303, 2003.

[40] D. Watson and A. Tellegen, "Toward a consensual structure of mood," Psychological Bulletin, vol. 98, 219-235, 2000.

[41] E. R. Hirt, R. J. Melton, H. E. McDonald, and J. M. Harackiewicz, "Processing goals, task interest and mood-performance relationship: A mediational analysis," Journal of Personality and Social Psychology, vol. 71, pp. 245-261, 1996.

[42] A. M. Isen, K. A. Daubman and G. P. Nowicki, "Positive affect facilitates creative problem solving," Journal of Personality and Social Psychology, vol. 52, pp. 1122-1131, 1987.

[43] A. M. Isen, M. M. S. Johnson, E. Mertz, and G. R. Robinson, "The influence of positive affect on the unusualness of word associations," 
Journal of Personality and Social Psychology, vol. 48, pp. 1413-1426, 1985.

[44] G. Kaufmann, "The effect of mood on creativity in the innovation process," The International Handbook on Innovation, Oxford, U.K.: Elsevier Science, pp. 191-203, 2003.

[45] S. K. Vosburg, "The effects of positive and negative mood on divergent thinking performance," Creativity Research Journal, vol. 11, pp. 165-172, 1998.

[46] J. M. George and J. Zhou, "Understanding when bad moods foster creativity and good ones don't: the role of context and clarity of feelings," Journal of Applied Psychology, vol. 87, pp. 687-97, 2002.

[47] L. L. Martin and P. Stoner, "Mood as input: What we think about how we feel determines how we think," Striving and Feeling: Interactions among Goals, Affect and Self-Regulation, Mahwah, NJ: Erlbaum, pp. 279-301, 1996.

[48] J. Kelly and S. Barsade, "Moods and emotions in small groups and work teams," Organizational Behavior and Human Decision Process, vol. 86, pp. 99-130, 2001.

[49] P. D. Cherulnik, K. A. Donley, T. S. R. Wiewel, and S. R. Miller, "Charisma is contagious, the effect of leader's Charisma on observer's affect," Journal of Applied Social Psychology, vol. 31, pp. 2149-2159, 2001.

[50] W. C. Tsai, H. W. Chen, and J. W. Cheng, "Employee positive moods as a mediator linking transformational leadership and employee work outcomes," The International Journal of Human Resource Management, vol. 20, no. 1, 206-219, 2009.

[51] J. M. George, "Emotions and leadership: The role of emotional intelligence," Human Relations, vol. 53, pp. 1027-1055, 2000.

[52] J. Rowold and A. Rohmann, "Transformational and transactional leadership styles, followers' positive and negative emotions and performance in German nonprofit orchestras," Nonprofit Management and Leadership, vol. 20, no. 1, pp. 41-59, 2009.

[53] A. M. Isen and R. A. Baron, "Positive affect as a factor in organizational behavior," Research in Organizational Behavior, vol. 13, pp. 1-53, 1991.

[54] J. M. George and A. P. Brief, "Feeling good - doing good: A conceptual analysis of the mood at work - organizational spontaneity relationship," Psychological Bulletin, vol. 112, pp. 310-329, 1992.

[55] C. D. Fisher, "Antecedents and consequences of real-time affective reactions at work," Motivation and Emotion, vol. 26, pp. 3-30, 2002.

[56] J. M. George, "State or trait: Effects of positive mood on prosocial behaviors at work," Journal of Applied Psychology, vol. 76, pp. 299-307, 1991.
[57] C. E. Izard, "Organizational and motivational functions of discrete emotions," Handbook of Emotions, New York: Guilford Press, 1993.

[58] G. R. Jones and J. M. George, "The experience and evolution of trust: Implications for cooperation and teamwork," Academy of Management Review, vol. 23, pp. 531-546, 1998

[59] J. L. Mwita, "Performance management model: A systems-based approach to public service quality," International Journal of Public Sector Management, vol. 13, 19-37, 2000.

[60] J. P. Campbell, R. A. McCloy, S. H. Oppler, and C. E. Sager, "A theory of performance," Personnel Selection in Organizations, San Francisco: Jossey-Bass, pp. 35-70, 1993.

[61] D. R. Ilgen and J. Schneider, "Performance measurement: A multi-discipline view," International Review of Industrial and Organizational Psychology, Chichester: Wiley, vol. 6, pp. 71-108, 1991.

[62] S. J. Motowidlo, W. C. Borman, and M. J. Schmit, "A theory of individual differences in task and contextual performance," Human Performance, vol. 10, pp. 71-83, 1997.

[63] J. K. Preacher and A. F. Hayes, "Asymptotic and resampling strategies for assessing and comparing indirect effects in multiple mediator models," Behavior Research Methods, vol. 40, no. 3, pp. 879-891, 2008.

[64] P. J. D. Carnevale and A. M. Isen, "The influence of positive affect and visual access on the discovery of integrative solutions in bilateral negotiation," Organizational Behavior and Human Decision Processes, vol. 37, pp. 1-13, 1986.

[65] R. J. Melton, "The role of positive affect in syllogism performance," Personality and Social Psychology Bulletin, vol. 21, pp. 788-794, 1995.

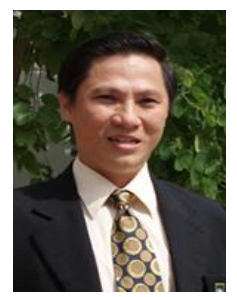

Mai Ngoc Khuong is a lecturer and researcher of School of Business Administration, International University, Vietnam National University, Ho Chi Minh City. He has a bachelor degree in tourism and hospitality management, master of science degree in leisure, tourism and environment at Wageningen University, The Netherlands and $\mathrm{PhD}$ degree in development management at School of Public Administration of the National Institute of Development Administration (NIDA), Bangkok, Thailand. 